TITLE:

\title{
Subgenomic replicon derived from a cell line infected with the hepatitis C virus(Abstract_要旨 )
}

AUTHOR(S):

Kishine, Hiroe

\section{CITATION:}

Kishine, Hiroe. Subgenomic replicon derived from a cell line infected with the hepatitis C virus. 京都大学, 2002, 博士(医学)

\section{ISSUE DATE:}

2002-07-23

URL:

http://hdl.handle.net/2433/149347

RIGHT: 


\begin{tabular}{|c|c|}
\hline 名 & 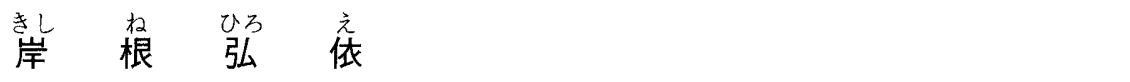 \\
\hline 学位(専攻分野) & \pm (医 学) \\
\hline 学 位 記 番 号 & 医 博 第 2524 号 \\
\hline 学位授与の日付 & 平成 14 年 7 月 23 日 \\
\hline 学位授与の要件 & 学 位規 則 第 4 条第 1 項 該 当 \\
\hline 研究科・専攻 & 医学研究科病理系専攻 \\
\hline 学位論文題目 & $\begin{array}{l}\text { Subgenomic replicon derived from a cell line infected with the hepa- } \\
\text { titis C virus } \\
\text { (培養細胞に感染したC 型肝炎ウイルスに由来するサブゲノムレプリコンの } \\
\text { 構築) } \\
\text { (主 查) }\end{array}$ \\
\hline
\end{tabular}

\section{論 文 内 容 $の$ 要 旨}

C 型肝炎ウイルス（hepatitis C virus；HCV）感染により引き起こされる肝炎は高率に慢性化し，その後これらの患者か ら高率に肝硬変及び肝癌が発症する。本ウイルスの感染による肝癌発症予防として持続感染を遮断してウイルスを排除する 方法がある。この目的でインターフェロン（IFN）を主にした治療が行われているが，治療成績は必ずしも満足できるもの ではない。このように治療成績を上げることができない理由の一つとして, HCV が培養細胞等に感染して効率よくウイル スを産生する系がないために，HCV と IFN の抗 HCV 効果との関連をきちんと評価する系がないことがあげられる。一方， ここ数年来 HCV ゲノムの一部分をレプリコンとした複製系が開発されてきた。この系はウイルスゲノムの一部分が効率よ く複製するためにゲノム複製機構の解析及び抗ウイルス凪の開発系として期待され，またIFN 感受性の解析にも有用であ る。しかし HCV ゲノム配列は多様性に富むこと，及び感染性を示すウイルス粒子を単離することが困難であることなどか ら，細胞内で複製しやすいレプリコンの構築は容易でなかった。この難点を克服するために培養細胞に感染し増殖した HCV ゲノムを単離し，それを用いて HCV ゲノムレプリコンを作成することを試みた。

まず，感染して僅かであるが HCV が増殖するヒト T 細胞株（MT-2）に HCV を感染させ 8 日間增殖させた。この細胞 から抽出した RNA を鋳型にしてRT-PCR 法により HCV ゲノム RNA に対する cDNA を得た。このcDNA からウイル スの構造タンパク質をコードする部分を除去し，その代わりに薬剤耐性因子であるネオマイシン耐性遺伝子を挿入し，更に HCV の非構造タンパク質を発現する領域の上流に脳心筋炎ウイルスの internal ribosomal entry site (IRES; RNA 内部り ボソーム結合部位）配列を挿入したプラスミドを構築した。本構造を持つ RNA からは HCV 非構造タンパク質が産生され， それにより HCV のサブゲノムが自己複製するためにネオマイシン而性遺伝子タンパク質が恒常的に産生されることが期待 される。実際に本 RNA を導入したヒト肝癌由来の培養細胞に㧈いては G418 耐性細胞クローンが得られた。本薬剤耐性細 胞に打いては導入したウイルスゲノムサイズと同じ大きさの RNA が検出された。また，放射性標識リン酸を用いた代謝標 識実験からサブゲノム RNA が実際に複製した結果生じたものであることが確認された。更にウイルスタンパク質の発現も 確認されたことから，得られた細胞では導入した HCV サブゲノム RNA がレプリコンとして持続的に複製されていること が分かった。

次に本細胞を用いて IFN に対するレプリコンの感受性を解析した。100IU/ml 濃度の IFN $\alpha$ 投与細胞に㧍いては，4 日後 のウイルスゲノム量は非投与細胞に比べて約1000分の 1 に低下した。

以上，培養細胞に HCV を一旦感染させることにより複製可能なウイルス RNA 濃縮し，そこから自己複製可能なウイ ルス RNA を単離することが可能であることが分かった。この系を用いることにより複数の HCV ゲノム配列から成るレプ リコンの作製が容易になることが期待される。したがってこの系は種々の HCV ゲノム配列と IFN の抗 HCV 効果との関 連を定量的に解析できる実験系の構築に有用なだけでなく，広く抗 $\mathrm{HCV}$ 郕を開発する研究，HCV の持続感染機構を解明 しウイルスを効率よく体内から排除するための研究にも資するところが多い。 


\section{論 文 審 査 $の$ 結 果 $の$ 要 旨}

$\mathrm{C}$ 型肝炎ウイルス $(\mathrm{HCV})$ による肝炎・肝がんの発症には本ウイルスの持続的感染が必要である。このことは HCVの 持続感染機構の解明が肝炎や肝がん発症の予防法の確立に必要であることを示唆する。しかし HCVを培養細胞で効率よく 増殖させる系が確立されてないため, 感染増殖機構の解明は進まず，効果的な抗 HCV 剤の開発にも至っていない。一方， 数年前に HCV ゲノムの一部分（欠損ゲノム）を効率よく複製させる系が開発された。この系は HCVの感染増殖を模擬す ると考えられるが, HCVゲノムの多様性が病態変化や抗ウイルス剂の効果に及ぼす解析にはゲノム配列の異なるレプリコ ン細胞の調製が必要である。しかし HCV 感染者の肝組織や血液中には感染性を示さないウイルスゲノムが多く含まれるた め, 感染性ウイルスゲノムを効率よく単離するのは容易でない。そこで本研究では培養細胞に感染増殖させた HCV RNA からのウイルスレプリコンの作成を行った。得られたRNA を導入した細胞では HCV RNAがレプリコンとして効率よく 持続的に複製することがわかった。またこのレプリコン量は細胞傷害を与えない量のインターフェロン処理に対して定量的 応答を示した。

以上の $\mathrm{HCV}$ 増殖実験系構築に関する研究は HCV の持続感染機構の解明やウイルスを効率よく体内から排除するための 研究，及び抗 $\mathrm{HCV}$ 剂の開発に寄与するところが多い。

したがって，本論文は博士 (医学) の学位論文として価值あるものと認める。

なお，本学位授与申請者は，平成14年 5 月 29 日実施の論文内容とそれに関連した試問を受け，合格と認められたものであ る。 